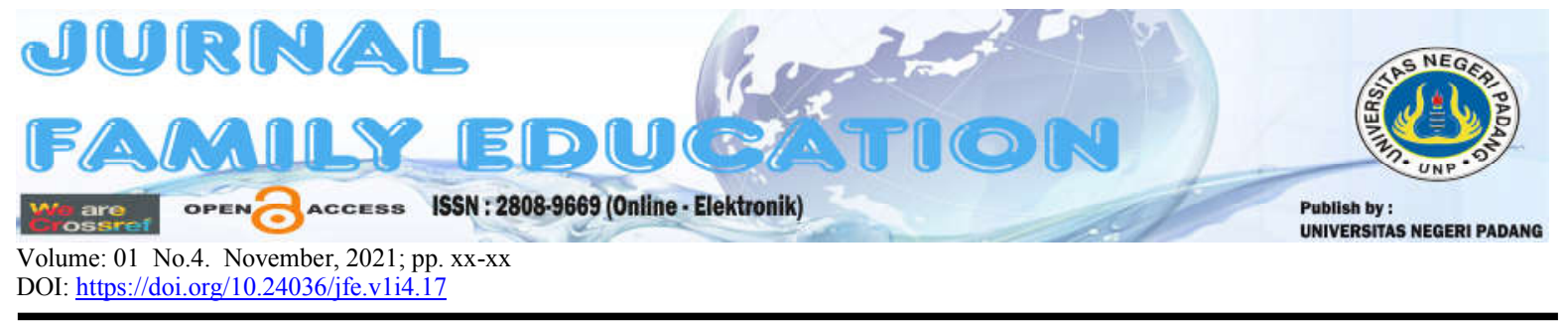

\title{
Kegiatan Parenting Orang Tua Terhadap Anak Di Era New Normal Di Kabupaten Pasaman Barat
}

\author{
Tria Citra, Asdi Wirman \\ universitas negeri padang \\ * e-mail: 98triacitra@gmail.com; asdiwirman@,fis.unp.ac.id
}

\begin{abstract}
The spread of Covid-19 has an impact on learning activities in schools. Therefore, this study aims to provide an overview of how parenting activities are carried out by parents for early childhood during the new normal period. Parents have different characteristics that affect the parenting applied and they are just adapting to the current state of the Covid-19 pandemic. This research uses descriptive quantitative method. The sampling technique used was non-probability sampling, data was collected using questionnaires and analyzed using descriptive statistics. Parenting activities carried out in the new normal period were carried out as usual activities but accompanied by new normal habits by implementing health protocols. Based on the research results, parents' answers on average rarely, sometimes and often implement new normal parenting activities. Parents who answered rarely worked as housewives because they were still indifferent to health protocols and thought that parenting activities had been carried out by teachers at schools. While sometimes and rarely are working parents such as civil servants, entrepreneurs and private employees, this is mostly due to the busy work of parents, but there are also some parents who have often implemented new normal parenting on the sidelines of their busy lives
\end{abstract}

Keywords: New Normal, Parenting Activities

(1) Licensees may copy, distribute, display and perform the work and make derivative works and remixes based on it only if they give the author or licensor the credits (attribution) in the manner specified by these. Licensees may copy, distribute, display, and perform the work and make derivative works and remixes based on it only for non-commercial purposes.

\section{PENDAHULUAN}

Pada masa sekarang Indondesia masih dalam kondisi terdampak Covid-19, dimana Corona Virus Disease ini lahir di tahun 2019. Maraknya khasus wabah COVID-19 di Indonesia menyebabkan proses pembelajaran berpindah belajar dari rumah yang disingkat dengan BDR yang diselenggarakan secara online. Hal ini direspon oleh Kemendikbud yang mengeluarkan surat edaran No. 15 Tahun 2020 tentang pedoman penyelenggaraan belajar dari rumah dalam masa darurat penyebaran Covid-19 dengan upaya untuk memutuskan rantai penyebaran virus ini.

Seiring berjalannya waktu, Indonesia beradaptasi dengan hal yang baru atau disebut dengan new normal. New Normal atau kenormalan baru digunakan dalam berbagai aktivitas terkait dengan suatu perbedaan yang sebelumnya dianggap tidak normal. New normal merupakan perubahan perilaku untuk tetap menjalankan aktivitas normal dengan ditambah penerapan protokol kesehatan guna mencegah terjadinya penularan Covid-19. Prinsip kenormalan ini ialah dapat menyesuaikan dengan pola hidup (Rosidi \& Nurcahyo, 2020)

Istilah parenting merujuk pada pola interaksi dan komunikasi orang tua dengan anak mereka keterlibatan orang tua meliputi segala tindakan dan dukungan kearah mempermudah dan 
membimbing pembelajaran serta mutu pendidikan bagi anak. (Mauanah \& Suprijono, 2016) mengatakan parenting merupakan cara orang tua dalam bertindak sebagai orang tua terhadap anak-anaknya, karena keluarga merupakan lingkungan kehidupan yang pertama kali dikenal oleh anak, sehingga pendidikan pertama anak diperoleh dalam kehidupan keluarga. Selanjutnya Wiranata dalam (Taufiqurrahman, 2020) menyatakan positive parenting merupakan pola asuh orang tua yang berlandaskan pada kasih sayang, perhatian, saling menghargai serta hubungan baik antara orang tua dengan anak. Dalam hal ini diharapkan pada orang tua untuk dapat menerapkan pengasuhan dengan memperhatikan karakteristik yang dimiliki oleh anak

Parenting merupakan serangkaian interaksi berkelanjutan antara orang tua dan anak. Perenting merujuk pada pola interaksi dan komunikasi orang tua dengan anak-anaknya, keterlibatan orang tua meliputi segala tindakan dan dukungan ke arah mempermudah dan membimbing pembelajaran dan mutu pendidikan bagi anak (Hayati \& Mamat, 2014). Interaksi dimaksudkan adalah hubungan individu dengan inividu lainnya, interaksi tersebut berbentuk kegiatan sehari-hari seperti pola asuh hubungan interaksi anatara orang tua dan anak. Pola asuh merupakan suatu model perlakuan atau tindakan orang tua dalam membina dan membimbing serta memelihara agar anak dapat berdiri sendiri (Anisah, 2017).

Pola asuh memiliki pola interaksi antara orang tua deangan anak. pola interaksi meliputi perilaku maupun sikap orang tua saat berhubungan dengan anak (Nugroho \& Dkk, 2017). Lebih dari itu pola asuh ini akan membentuk watak dan karakter anak di masa dewasanya. Idealnya kegiatan parenting adalah kegiatan mengasuh sedangakan dimasa new normal saat ini peralihan model pembelajaran konvensional ke pembelajaran online di masa new normal membutuhkan pendampingan dari orang tua parenting untuk memperlancar kegiatan pembelajaran yang dilakukan di rumah (Wahyuni \& Asfahani, 2021).

Berdasarkan observasi awal dan wawancara yang peneliti lakukan di TK Pembina Pasaman Nagari Aua Kuniang Kecamatan Pasaman Kabupaten Pasaman Barat. Orang tua anak memiliki latar belakang yang berbeda seperti dari segi pekerjaan dimana pekerjaan mempengaruhi kegiatan parenting yang dilakukan orang tua terhadap anak. Berdasarkan wawancara yang peneliti lakukan terhadap salah satu orang tua yang bekerja sebagai guru dimana ia mengalami masalah dalam menerapkan kegiatan parenting bersama anak hal tersebut dikarenakan orang tua bekerja, setiap paginya orang tua sudah pergi bekerja dan anak ditinggal dirumah bersama pengasuh atau kerabat hal tersebut membuat berkurangnya waktu orang tua bersama anak. Selain itu kesibukan membuat orang tua memiliki peran ganda sehingga membuat orang tua kewalahan untuk selalu memperhatikan kegiatan parenting bersama anak. Peneliti juga mewawancarai orangtua anak yaitu ibu rumah tangga, ibu tersebut menjawab tidak ada kesulitan dalam mengasuh anak namun orang tua tersebut terkesan bebas dalam pengasuhan anak, anak dibiarkan bermain diluar tanpa menerapkan protokol kesehatan. Fenomena tersebut sejalan dengan pendapat (Hayati \& Mamat, 2014) faktor yang mempengaruhi parenting adalah latar belakang guru dan orang tua itu sendiri seperti pendidikan dan status sosial ekonomi orang tua, alasan yang sering disebutkan adalah kesibukan kerja, tidak ada waktu dan tidak berpengalaman. Mereka menganggap bahwa pendidikan anak sudah mencukupi dan memedai dengan apa yang diperoleh dari guru sekolah. Oleh karena itu dikarenakan beragamnya latar belakang orang tua anak hal dan pola asuh yang diterapkan orang tua selama masa new normal peneliti tertarik untuk melihat bagaimana gambaran kegiatan parenting yang dilakukan orang tua selama masa new normal. 


\section{METODE}

Jenis penelitian yang digunakan dalam penelitian ini ialah jenis penelitian kuantitatif (Sugiyono, 2016). Populasi pada penelitian ini adalah orang tua anak-anak di TK Pembina Pasaman yang berjumalah 88 orang. Penelitian ini menggunakan teknik pengumpulan data kusioner (angket) yang akan menggunakan pernyataan tertulis dengan kategori gambaran kegiatan parenting yang dilakukan orang tua di masa new normal. dianalisis secara deskriptif kuantitatif.

\section{HASIL DAN PEMBAHASAN}

Hasil penelitian kegiatan parenting yang dilakukan orang tua bersama anak usia dini di masa new normal di TK Pembina Pasaman Nagari Aua Kuniang Kabupaten Pasaman Barat secara keseluruhan dihasilkan 23 orang tua rata-rata jarang melakukan kegiatan selama masa new normal dengan menerapkan protokol kesehatan selama masa new normal, 55 responden atau orang tua kadang-kadang melakukan kegiatan parenting selama masa new normal dengan menerapkan protokol kesehatan selama masa new normal dan 10 responden atau orang tua yang sudah sering melakukan kegiatan parenting selama masa new normal dengan menerapkan protokol kesehatan selama masa new normal.

Menurut (Kurniati \& Dkk, 2021) Keluarga atau orang tua merupakan elemen yang tidak bisa dipisahkan dari kehidupan anak, karena keluarga merupakan tempat pertama anak memulai kehidupannya. Banyak nilai yang dapat diajarkan kepada anak dari sebuah keluarga yaitu nilainilai agama, nilai sosial, kreativitas, kebiasaan dan pola hidup serta masih banyak lainnya.

Selama menerapkan kegiatan parenting di masa new normal orang tua yang rata-rata menjawab jarang menerapkan kegiatan parenting bukan berarti mereka tidak sayang kepada anak, anak-anak yang dibiarkan main diluar rumah merupakan pengasuhan yang diterapkan oleh orang tua kepada anak agar anak tidak merasa bosan dirumah terus dan orang tua menganggap bermain adalah kebutuhan anak melalui bermain diluar anak memperoleh pengalaman secara langsuang dan belajar bersosialisasi dengan lingkungannya oleh karena itu orang tua membiarkan anak bermain bebas diluar hal tersebut sejalan dengan Pendapat Dewi (2019) dalam (Anwar \& N, 2020) orang tua kepada anak di era new normal merupakan kegiatan yang tidak hanya pemberian rasa nyaman kepada anak dan menjauhkan anak dari pengaruh dan perilaku menyimpang tetapi orang tua juga harus turut memperhatikan aktivitas mengenai kesehatan dan keselamatan anak-anak agar terhindar dari covid-19. Pengasuhan merupakan suatu aspek penting dalam membentuk perkembangan diri anak. Orang tua tentu memerlukan pengetahuan dan keterampilan yang memadai agar dapat memberikan pengasuhan yang benar bagi anak. Pengetahuan pengasuhan meliputi memahami cara merawat anak- anak, dan peran yang beragam orang tua bermain dalam kehidupan anak-anak. pengasuhan yang dilakukan orang tua yang umum seperti memberikan kebutuhan fisik rata-rata orang tua sudah sering menerapkan kegiatan pemenuhan kebutuhan fisik anak seperti memenuhi asupan gizi anak, menyediakan obat ketika anak sakit dan mengajak anak berolahraga apalagi di masa new normal ini kebiasaan untuk memperkuat imun tubuh dengan berjemur di pagi hari. Pengetahuan pengasuhan termasuk memahami berbagai pendekatan yang tepat untuk memenuhi kebutuhan fisik dan biologis dan sosioemosional dan kognitif anak-anak ketika mereka berkembang (Damon et al., 2006). Pendapat (Anggraini et al., 2021) mengungkapkan Pre-arming menurut teknik pengasuhan komunikasi yang diadakan oleh orangtua dan anak dalam menyelesaikan masalah atau dalam menjalin hubungan yang nyaman antara orang tua dengan anak. Komunikasi antara orang tua dengan anak masih cukup baik terlihat dari kebiasaan orang tua dalam memulai komunikasi seperti dengan sengaja memancing anak untuk 
bercerita dengan bertanya sesuatu hal yang dilakukannya hari ini. Pre-arming bukan hanya bertujuan agar anak dan orangtua saling berkomunikasi dalam memecahkan permasalahan, akan tetapi komunikasi dapat berlangsung meskipun tanpa adanya permasalahan, semestinya hubungan komunikasi orang tua dan anak harus terjalin dengan seimbang untuk menciptakan kerukunan dan saling menyayangi antar anggota keluarga.

Walaupun orang tua mayoritas kadang-kadang menerapkan kegiatan parenting new nomal, parenting tidak hanya dari orang tua saja anggota keluarga seperti nenek, kakek, adik dan kakak sera kerabat lainnya dapat menerapkan kegiatan parenting keapada anak usia dini dengan memperhatikan kegiatan anak dan memberikan contoh yang baik. Sejalan dengan pendapat (Permono, 2013) Keluarga dapat berperan sebagai fondasi dasar untuk memulai langkah-langkah pembudayaan karakter melalui pembiasaan bersikap dan berperilaku sesuai dengan karakter yang diharapkan. Kegiatan parenting dilakukan dengan selalu di terapkan setiap hari agar anak selalu mengulang kegiatan tersebut dan selanjutnya menjadi terbiasa. Pembiasaan yang disertai dengan teladan dan diperkuat dengan penanaman nilai. Sejalan dengan pendapat (Ihsan et al., 2018) Penanaman disiplin sangat penting diterapkan orang tua karena anak usia dini ingatannya belum kuat, belum bisa terlalu fokus, cepat bosan dan cepat beralih kepada hal-hal baru lainnya. Apabila penanaman disiplin diterapkan sejak usia dini maka dewasa anak akan bersikap disiplin. Penerapan disiplin sejak usia dini mempermudah orang tua untuk memperbaiki perilaku menyimpang anak sehingga kebiasaan disiplin anak akan mudah diterima di masyarakat dan anak akan lebih bahagia.

Pendapat (Verawaty \& Izzati, 2020) Salah satu caranya menerapkan perilaku disiplin anak adalah dengan memberi reward atau penghargaan. Reward merupakan ganjaran atau hadiah sebagai hasil usaha. Menurut (Suparmi, 2019) Reward adalah usaha untuk menumbuhkan pengakuan dan perasaan di lingkungan berupa apresiasi baik materi atau ucapan atas suatu prestasi. Pemberian reward kepada anak diharapkan anak dapat mempertahankan dan meningkatkan pencapaiannya di waktu yang akan datang.

Menurut Gunadi 2008 dalam (Akhyadi \& Mulyono., 2018) menyatakan bahwa terdapat 3 peran utama orang tua dalam mendukung perkembangan karakter anak selama di rumah pada masa new normal. (1) Pertama, orang tua harus mampu menciptakan suasana yang kondusif, hangat serta tentram, karena dengan begitu anak akan merasa nyaman untuk belajar apapun. (2) Kedua, orang tua harus mampu menjadi contoh atau panutan yang positif bagi anak, karena anak usia dini merekam dan belajar banyak atas apa yang dilihatnya. Karakter orang tua yang ditunjukkan dalam tindakan nyata merupakan bahan ajar yang akan diserap dan diingat oleh anak. (3) Ketiga, orang tua harus mampu mendidik anak agar dapat berperilaku sesuai dengan aturan atau norma yang diajarkan oleh orang tua. Oleh karena itu, pada masa new normal ini maka sangat penting bagi orang tua karena proses tumbuh kembang anak itu berjalan seiring dengan waktu dan berjalan secara gradual sehingga masanya tidak dapat diulang kembali.

\section{KESIMPULAN}

Kegiatan parenting merupakan kegiatan pengasuhan yang dilakukan oleh orang tua. Selam masa new normal kegiatan parenting disesuaikan dengan kebiasaan-kebiasaan new normal seperti memakai masker, menjaga jarak, menghindari keramaian dan mencuci tangan dengan bersih menggunakan sabun atau penggunaan handsanitizer. Kegiatan parenting menjadi suatu perhatian yang dilakukan orang tua dimana waktu anatara orang tua dan anak lebih banyak dilakukan 
dirumah. Kegiatan parenting dilakukan berdasarkan pola asuh yang diterapkan oleh orang tua. Kegiatan parenting yang dilakukan orang tua dilakukan dengan teknik parenting diantaranya disiplin, monitoring, reward, everyday routine dan prearming. Metode penerapan teknik parenting merupakan upaya orang tua memfasilitasi perilaku dan pembentukan karakter anak agar dapat diterima di masyarakat.

Berdasarkan hasil penelitian dan pembahasan mengenai kegiatan parenting yang dilakukan orang tua bersama anak usia dini di masa new normal di TK Pembina Pasaman Nagari Aua Kuniang Kabupaten Pasaman Barat dapat disimpulkan 23 orang tua rata-rata jarang menerapkan kegiatan parenting new normal, 55 responden kadang-kadang menerapkan kegiatan parenting new normal dan 10 orang tua sering menerapkan kegiatan parenting new normal. Orang tua yang menjawab jarang mayoritas berkerja sebagai ibu rumah tangga dikarenakan mereka masih acuh terhaadap protokol kesehatan dan menggaggap kegiatan parenting sudah dilakukan oleh guru di sekolah. Sedangkan kadang-kadang dan jarang adalah orang tua yang berkeja seperti PNS, Wiraswasta dan Pegawai Swasta hal tersebut kebanyakan disebabkan kesibukan pekerjaan orang tua namun ada juga beberapa orang tua yang sudah sering menerapkan parenting new normal di sela-sela kesibukannya

\section{REFERENSI}

Akhyadi, A. ., \& Mulyono. (2018). Program Parenting dalam Meningkatkan Kualitas Pendidikan Keluarga. 1(1), 1-8.

Anggraini, A., I, N., \& A, S. (2021). Teknik Pengasuhan Orang Tua Terhadap Kemandirian Anak Usia Dini pada Keluarga Mantan Gelandangan dan Pengemis di Desa Prodo Kecamatan Winongan Kabupaten Pasuruan.

Anisah, A. Si. (2017). Pola Asuh Orang Tua dan Implikasinya Terhadap Pembentukan Karakter Anak. Jurnal Pendidikan Universitas Garut Fakultas Pendidikan Islam Dan Keguruan, 5(1), 70-84.

Anwar, R. ., \& N, A. (2020). Pengasuhan Anak Usia Dini di Era New Normal Perspektif Islam. Jurnal Pendidikan Islam Anak Usia Dini, 2(2), 1-9.

Damon, W., Lerner, \& M, R. (2006). Handbook Of Child Psychology (6th ed., Vol. 4).

Hayati, F., \& Mamat, N. (2014). Pengasuhan dan Peran Orang Tua (Parenting) Serta Pengaruhnya Terhadap Perkembangan Sosial Emosional Anak di Paud Banda Aceh. Jurnal Buah Hati, 1(2), 16-30.

Ihsan, N., Kurniah, N., \& Suryapti, A. (2018). Hubungan Metode Pembiasaan Dalam Pembelajaran dengan Disiplin Anak Usia Dini. Jurnal Polensia, 3(1), 50-55.

Kurniati, \& Dkk. (2021). Analisis Peran Orang Tua dalam Mendampingi Anak di Masa Pandemi Covid-19. Jurnal Obsesi: Jurnal Pendidikan Anak Usia Dini, 5(1).

Mauanah, S. ., \& Suprijono. (2016). Parenting Education Sebagai Pendidikan Keluarga. Jurnal Pradigma, 4(1), 1-10.

Nugroho, A. D., \& Dkk. (2017). Pola Asuh Si Kecil Di Era Digital Pada Masa New Normal. Jurnal Pengabdian Kepada Masyarakat, 3(2), 132.

Permono, H. (2013). Peran Orang Tua dalam Optimalisasi Tumbuh Kembang Anak Membangun Karakter Anak Usia Dini. Prosiding Seminar Nasional 2013. 
Rosidi, A., \& Nurcahyo, E. (2020). Penerapan New Normal (Kenormalan Baru) dalam Penanganan Covid-19 Sebagai Pandemi dalam Hukum Positif. Jurnal Ilmiah RInjani, 8(2), 193197.

Sugiyono. (2016). Metode Penelitian Pendidikan (Pendekatan Kuantitatif, Kualitatif dan R\&D). Alfabeta.

Suparmi, V. S. (2019). Reward dan Punishment Sebagai Pemicu Kinerja Karyawan pada PT. Dunia Setia Sandang Asli IV Ungaran. Jurnal Ilmiah UNTAG Semarang, 8(1), 52.

Taufiqurrahman, M. (2020). Pendidikan Perlikau Hidup Sehat dan Bersih Perspektif Pendidikan Islam Bagi Anak Usia Dini dalam Kenormalan Baru Covid-19. Jurnal Pendidikan Anak Usia Dini, 1(1), 83-96.

Verawaty, \& Izzati. (2020). Hubungan Pemberian Reward terhadap Perilaku Disiplin Anak Usia Dini. Jurnal Pendidikan Tambusai, 4(2).

Wahyuni, F., \& Asfahani. (2021). Parenting: Menjadi orang Tua Kreatif Bagi Anak Usia Dini Di masa Masa New Normal. Journal of PsiYchologi and Development, 1(1). 